Coleman, G. S. (1960). J. gen. Microbiol. 22, 423-436

\title{
A Sulphate-Reducing Bacterium from the Sheep Rumen
}

\author{
By G. S. COLEMAN
}

Agricultural Research Council Institute of Animal Physiology, Babraham, Cambridge

SUMMARY: A spore-forming, mesophilic, sulphate-reducing bacterium has been isolated from the rumen of hay-fed sheep. The organism is an obligately anaerobic Gram-negative rod which, in the presence of sulphate and $0.1 \%$ yeast extract, used only L- or D-alanine, DL-lactate, pyruvate or formate, but not 47 other compounds tested, as hydrogen donor for growth. Under these conditions the sulphate could be replaced by sulphite or thiosulphate. The yeast extract was replaceable by ferrous sulphate $+p$-aminobenzoic acid + biotin. Evidence is presented that alanine and lactate are metabolized via pyruvate which breaks down to form acetate and formate, the latter then being metabolized to form $\mathrm{CO}_{2}$. The growth of the organisms was inhibited when the concentration of sulphide reached $6-7 \mu \mathrm{mole} / \mathrm{ml}$. and the maximum dry weight was only $50-60 \mu \mathrm{g} . / \mathrm{ml}$. Washed suspensions of the organism in $2.0 \%$ yeast extract utilized gaseous hydrogen for sulphate reduction and $\mathrm{H}_{2}: \mathrm{H}_{2} \mathrm{~S}$ ratios of 3.2-4.0 were obtained.

Block \& Stekol (1950) and Block, Stekol \& Loosli (1951) showed that ${ }^{35}$ Ssulphate administered to sheep was incorporated into the cystine and methionine of the rumen micro-organisms and the milk of the animal. Emery, Smith \& Huffman (1957), using cattle rumen contents, demonstrated an in vitro incorporation of ${ }^{35} \mathrm{~S}$ from inorganic sulphate into organic sulphur compounds but found from microradioautographs of the material that the majority of the organisms did not incorporate radioactivity. Emery, Smith \& Fai To (1957) further demonstrated that only five pure cultures of rumen organisms out of ten utilized inorganic sulphate for the synthesis of organic sulphur compounds. It is possible that the first step before sulphate can be utilized by at least some of the rumen micro-organisms is a reduction to sulphide, and Lewis (1954) and Anderson (1956) demonstrated that this reaction occurred in the rumen and in washed suspensions of rumen bacteria in vitro. These authors suggested that an organism similar to Desulphovibrio desulphuricans was responsible for this reduction and Gutierrez (1953) isolated an organism from cattle that might have been a Desulphovibrio sp.

The present work was undertaken in an attempt to isolate and characterize the sulphate-reducing bacteria present in the rumen, and in this paper one such bacterium is described. A preliminary communication concerning this organism has already appeared (Coleman, 1959).

\section{METHODS}

Sources of material. One organism (strain DL) was isolated from a crude culture kindly given by $\mathrm{Dr} \mathrm{D}$. Lewis. This culture was a completely filled and sealed bottle of medium which had been inoculated from the rumen 
contents of a hay-fed sheep dosed with sodium sulphate (Lewis, 1954), incubated and then kept at $4^{\circ}$ for 5 years.

Another strain (42) was isolated from the fresh rumen contents of a hay-fed Clun Forest sheep.

Basal media. All the media used were based on the media of Butlin, Adams $\&$ Thomas (1949). For the isolation of the organisms the medium (A) used had the composition (g./litre): $\mathrm{K}_{2} \mathrm{HPO}_{4}, 1 \cdot 0 ; \mathrm{NH}_{4} \mathrm{Cl}, 1 \cdot 0 ; \mathrm{Na}_{2} \mathrm{SO}_{4} \cdot 10 \mathrm{H}_{2} \mathrm{O}, 2 \cdot 0$; $\mathrm{MgSO}_{4} .7 \mathrm{H}_{2} \mathrm{O}, \mathbf{2} \cdot 0 ; \mathrm{CaCl}_{2}$-dried, $0 \cdot 1 ; 70 \%(\mathrm{w} / \mathrm{v})$ sodium lactate, $5 ;$ Difco yeast extract, $1 ; \mathrm{FeSO}_{4} .\left(\mathrm{NH}_{4}\right)_{2} \mathrm{SO}_{4} \cdot 6 \mathrm{H}_{2} \mathrm{O}, 0 \cdot 1$ (this was autoclaved separately and added to the medium just before inoculation). For the experiments with pure cultures the following basal salts were used and contained g./litre: $\mathrm{K}_{2} \mathrm{HPO}_{4}$, $1.0 ; \mathrm{NH}_{4} \mathrm{Cl}, 0.07 ; \mathrm{MgCl}_{2} .6 \mathrm{H}_{2} \mathrm{O}, 1 \cdot 7 ; \mathrm{CaCl}_{2}$-dried, $0 \cdot 1 ; \mathrm{Na}_{2} \mathrm{SO}_{4} .10 \mathrm{H}_{2} \mathrm{O}, 3 \cdot 22$ $(10 \mu \mathrm{mole} / \mathrm{ml}$.). All chemicals were of 'Analar' quality where possible. Both the basal salts and medium $A$ were autoclaved and filtered clear before use. Medium B contained basal salts plus $0.05 \%$ yeast extract and medium $\mathrm{C}$ contained basal salts plus $2.5 \%$ yeast extract. All media were autoclaved at $10 \mathrm{lb}$./sq.in. for $20 \mathrm{~min}$. and either used immediately afterwards or steamed for $1 \mathrm{hr}$. before use to remove dissolved air.

Rumen fluid was prepared from crude rumen contents by straining through one layer of muslin, centrifuging at $30,000 \mathrm{~g}$ for $50 \mathrm{~min}$. to remove bacteria and autoclaving in sealed McCartney bottles under $95 \%(\mathrm{v} / \mathrm{v}) \mathrm{N}_{2}+5 \%(\mathrm{v} / \mathrm{v}) \mathrm{CO}_{2}$. Sodium sulphite, sodium thiosulphate, L-cysteine, sodium acrylate and ascorbate were made up freshly each time before use and sterilized by Seitz filtration under negative pressure. Sodium bicarbonate was sterilized by Seitz filtration under positive pressure.

For all the experiments with pure cultures $0.2 \%(w / v)$ ascorbic acid was added to the medium immediately before inoculation.

Incubation conditions. All experiments except those in sealed tubes were carried out in cotton-plugged test tubes incubated in McIntosh-Fildes jars, filled with $95 \%(\mathrm{v} / \mathrm{v}) \mathrm{H}_{2}+5 \%(\mathrm{v} / \mathrm{v}) \mathrm{CO}_{2}$ by alternate evacuation and admission of gas until the final air content was less than $0 \cdot 1 \%$. No catalyst was used. All cultures were incubated at $39^{\circ}$ except where stated.

Isolation of pure cultures. The final isolation procedure was as follows. Fresh rumen fluid or cultures which had been incubated for over 4 weeks were heated to $75^{\circ}$ for $60 \mathrm{~min}$. before plating out in layer plates prepared from the medium A solidified with $1 \%$ agar (Davis Gelatine Ltd., London, E.C. 3). The lower layer (10 ml.) contained $10 \%$ autoclaved rumen fluid, $0.2 \%$ ascorbic acid and the inoculum, and when solid was covered with $200 \mathrm{ml}$. of agar containing $3.0 \%$ $\mathrm{Na}_{2} \mathrm{SO}_{3} \cdot 7 \mathrm{H}_{2} \mathrm{O}$. The plates were then incubated aerobically. Black colonies which formed in the lower layer, and which, as seen under the microscope, were free from contaminating colonies, were picked off into medium A plus $10 \%$ autoclaved rumen fluid plus $0 \cdot 2 \%$ ascorbic acid or $3 \% \mathrm{Na}_{2} \mathrm{SO}_{3} \cdot 7 \mathrm{H}_{2} \mathrm{O}$. Subcultures were then made on solid media and the process repeated until a pure culture was obtained.

When the cultures were microscopically homogeneous and had been trained to grow on media to which no iron had been added the organisms were plated 
out as follows. Layer plates were prepared as described above except that the iron salt and autoclaved rumen fluid were omitted from the medium and the ascorbate or sodium sulphite was replaced by $0.05 \%(w / v) L-c y s t e i n e$. The lower layer was inoculated with $1 \mathrm{ml}$. of a $10^{7}$ dilution of a fully grown culture (c. $10^{8}$ bacteria $/ \mathrm{ml}$.) in medium $\mathrm{C}$ plus $0.05 \% \mathrm{~L}$-cysteine. Under these conditions $c$. ten colonies per plate appeared and could easily be picked off.

Confirmation that the cultures were pure was obtained by inoculation of conventional laboratory media followed by incubation under aerobic and anaerobic conditions and by the 'rough agar dilution' method of Postgate (1953). Only one morphological type was ever found and when such cultures were inoculated into medium B + lactate growth was always associated with sulphide formation.

Preservation of the organism. Stock cultures were kept in medium C plus $0.2 \%$ ascorbate and subcultured every week. Except where stated the characteristics of the organisms were determined after 2-4 days growth under these conditions.

Quantitative and nutrition experiments. These were carried out in $c .16 \mathrm{ml}$. tubes fitted with $\mathrm{C} 14$ stoppers. The tubes were autoclaved containing $8 \mathrm{ml}$. basal salts (twice the given concentration) plus other stable compounds and then after the addition of Seitz-filtered reagents, inoculated with a $0.5 \%(\mathrm{v} / \mathrm{v})$ inoculum, completely filled with sterile water and stoppered. Glass beads were added to the tubes to facilitate mixing. For experiments in which dry weights were determined, completely filled c. $170 \mathrm{ml}$. stoppered conical flasks were used. Experiments in which samples were required at intervals were either carried out in a series of $170 \mathrm{ml}$. flasks or in a $5 \mathrm{l}$. flask from which samples were blown at intervals with $95 \%(\mathrm{v} / \mathrm{v}) \mathrm{N}_{2}+5 \%(\mathrm{v} / \mathrm{v}) \mathbf{C O}_{2}$. Similar results were obtained by both methods. All solutions were adjusted to $\mathrm{pH}$ of $6.5-7 \cdot 0$ with $\mathrm{NaOH}$ before addition to the tubes.

Washed suspension techniques. The organism was grown for $2 \frac{1}{2}$ days anaerobically in $500 \mathrm{ml}$. flasks on medium $\mathrm{C}$, harvested, washed once in $2.0 \%$ yeast extract $+\mathbf{0 . 2} \%$ ascorbate and finally suspended at a density of 1-5 mg. dry wt. $/ \mathrm{ml}$. in $2.0 \%$ yeast extract $+0.2 \%$ ascorbate. The experiments were carried out in double side-bulb Warburg manometers at $40^{\circ}$. Each flask contained $0.5 \mathrm{ml} .0 .05 \mathrm{M}$-tris (hydroxymethyl) amino methane buffer $\mathrm{pH} 7 \cdot 1$ plus $1.0 \mathrm{ml}$. bacterial suspension in the main compartment and $0.5 \mathrm{ml}$. of the substrate was added from one side arm after a $10 \mathrm{~min}$. period of equilibration. The reactions were terminated by the addition of $0.4 \mathrm{ml}$. $\mathrm{M}_{-} \mathrm{H}_{3} \mathrm{PO}_{4}$ from the second side arm. Controls in which the acid was added at the same time as the substrate were always carried out. Except where stated, the gas phase was $100 \% \mathrm{H}_{2}$ and a $\mathrm{CdCl}_{2}$ paper was present in the centre well to absorb $\mathrm{H}_{2} \mathrm{~S}$ evolved. At the end of the experiment the contents of each manometer vessel were washed out, made up to $10 \mathrm{ml}$. with water, the bacteria centrifuged out and the supernatant fluid further clarified by passage through a Ford Sterimat CC/01. Samples of the supernatant fluid were used for sulphate determinations.

Sulphide estimations. The method was based on that of Postgate (1951) and Vogel (1948). Because of the risk of oxidation, sulphide determinations were 
performed only on those growth experiments carried out in completely filled and sealed tubes. One $\mathrm{ml}$. of the culture fluid was rapidly pipetted into $1.0 \mathrm{ml}$. $\mathrm{N}-\mathrm{NaOH}$ in the main compartment of a Warburg flask. The manometer was gassed with $\mathrm{H}_{2}$ and after equilibration at $40^{\circ}$ the sulphide was liberated by the addition of $0.5 \mathrm{ml} .10 \mathrm{~N}-\mathrm{H}_{2} \mathrm{SO}_{4}$ and absorbed on a paper soaked in $0.2 \mathrm{ml} .50 \%$ $\mathrm{CdCl}_{2}$. After at least $3 \mathrm{hr}$., the paper was transferred to a stoppered test tube containing 1.0-3.0 ml. 0.02 $\mathrm{M}-\mathrm{I}_{2}$ and $3 \mathrm{ml} .5 \mathrm{~N}-\mathrm{HCl}$, which was shaken and left for $5 \mathrm{~min}$. The centre well was washed out with the titration liquid, followed by distilled water and the washings added to the titration vessel. The whole volume was back titrated with $0.002 \mathrm{M}-\mathrm{Na}_{2} \mathrm{~S}_{2} \mathrm{O}_{3}$, using 2 drops $1 \%$ starch as indicator while a stream of $\mathrm{O}_{2}$-free $\mathrm{N}_{2}$ was passed through the solution. Under these conditions standard sulphide solutions containing $0-20 \mu \mathrm{mole} / \mathrm{ml}$. gave results which were consistently $18 \%$ lower than that obtained by titrating the sulphide solutions directly and all sulphide determinations have been corrected accordingly. For the estimation of sulphide produced during washed suspension experiments, $3 \mathrm{hr}$. was allowed for the absorption of the sulphide by the $\mathrm{CdCl}_{2}$ paper after the addition of the $\mathrm{H}_{3} \mathrm{PO}_{4}$ and then the paper dropped into $\mathrm{I}_{2}-\mathrm{HCl}$ as before.

For the determination of ${ }^{35} \mathrm{~S}$ in $\mathbf{H}_{2}{ }^{35} \mathrm{~S}$ the sulphur precipitate produced from the sulphide in the above reaction was washed twice with water on the centrifuge and then a known proportion of the material plated out for radioactivity determination so that the mass of material did not exceed $0.5 \mathrm{mg} . / \mathrm{cm} .^{2}$ of the disk. The radioactivity was estimated by the usual method modified as described for ${ }^{14} \mathrm{C}$ by Coleman (1958).

Sulphate estimation. For the estimation of small quantities, a nephelometric barium sulphate precipitation method based on that of Obermer \& Milton (1932) was used. A sample of the filtered and diluted supernatant fluid from the washed suspension experiment containing 100-300 $\mu \mathrm{g}$. sulphate-sulphur was placed in a $25 \mathrm{ml}$. measuring cylinder together with $1.5 \mathrm{ml} .10 \% \mathrm{NaCl}$ and $1.7 \mathrm{ml} .5 \mathrm{~N}-\mathrm{HCl}$ and made up to $20 \mathrm{ml} .5 \mathrm{ml}$. of the nephelometric solution of Obermer \& Milton prepared from Evans peptone (Evans Medical Supplies Ltd., London) was blown in rapidly, the whole mixed, allowed to stand for $\mathbf{3 0} \mathrm{min}$., remixed and the optical density estimated on a Spekker photoelectric absorptiometer with violet filters and $4 \mathrm{~cm}$. cells. Standard solutions were included in each estimation and were treated in the same way as the unknown solutions throughout; the optical density was non-linearly related to sulphate concentration up to $400 \mu \mathrm{g}$. sulphate-sulphur $/ 25 \mathrm{ml}$. In the growth experiments where sufficient material was present, the gravimetric barium sulphate precipitation method of Vogel (1948) was used.

Ammonia was estimated spectrophotometrically with Nessler's reagent after distillation in a Markham microdistillation apparatus (Markham, 1942) from a strongly alkaline solution. Alanine was determined by the ninhydrin method as described by Coleman (1956). Lactate was estimated by the method of Barker \& Summerson (1941). Total volatile fatty acids were determined by steam distillation from $c .0 \cdot 3 \mathrm{M}$-phosphate buffer $(\mathrm{pH} \mathrm{2.5})$ in a Markham microdistillation apparatus and titration of the distillate with $0.01 \mathrm{~N}-\mathrm{NaOH}$ in a 


\section{Sulphate-reducing bacterium}

stream of $\mathrm{CO}_{2}$-free air. Under these conditions lactic acid was non-volatile. For qualitative determination of the acids present the distillate was evaporated to a suitable volume and analysed chromatographically by the method of Elsden \& Lewis (1953).

Dry weights were determined after washing the organisms twice with water on the centrifuge, by drying to constant weight at $105^{\circ}$.

Special reagents. Acrylic acid (L. Light and Co. Ltd.) was steam distilled before use. ${ }^{35} \mathrm{~S}$-Sodium sulphate was supplied by the Radiochemical Centre, Amersham, Buckinghamshire.

\section{RESULTS}

\section{Growth experiments}

Growth of crude cultures. During the isolation procedures sulphide production was detected by blackening of the medium, caused by ferrous sulphide formation. Preliminary experiments carried out in completely filled and sealed bottles showed that it was necessary to add $0 \cdot 1 \%$ yeast extract to the lactate + salts before sulphide production occurred from a $0.05 \%(\mathrm{v} / \mathrm{v})$ fresh rumen fluid inoculum. This blackening disappeared on subculture, although there was heavy bacterial growth, and the addition of $10 \%(\mathrm{v} / \mathrm{v})$ autoclaved rumen fluid and $3.0 \%(\mathrm{w} / \mathrm{v}) \quad \mathrm{Na}_{2} \mathrm{SO}_{3} \cdot 7 \mathrm{H}_{2} \mathrm{O}$ was necessary before transferable black material was obtained. Insufficient of the causative organism was present to enable a pure culture to be obtained after plating and it was first necessary to heat the inoculum to $75^{\circ}$ for $60 \mathrm{~min}$. to kill some of the contaminating organisms. This treatment would eliminate Desulphovibrio desulphuricans from the enrichments and it is therefore possible that the organism isolated was not the most important sulphate-reducing rumen bacterium.

Serial tenfold dilutions of fresh rumen contents from a hay-fed sheep made in the medium $A$ plus $10 \%$ autoclaved rumen fluid and $3.0 \% \mathrm{Na}_{2} \mathrm{SO}_{3} .7 \mathrm{H}_{2} \mathrm{O}$ or $0.2 \%$ ascorbate and carried out in sealed bottles showed blackening corresponding to only 100 organisms $/ \mathrm{ml}$. This result indicated either that an insignificant number of sulphate-reducing bacteria were present or that in the higher dilutions the growth of other bacteria prevented the development of sulphide-producing bacteria.

Growth of pure cultures. Microscopically homogeneous cultures of both strains grew equally well with blackening of the medium when the $\mathbf{3 . 0} \%$ $\mathrm{Na}_{2} \mathrm{SO}_{3} .7 \mathrm{H}_{2} \mathrm{O}$ was replaced by $0 \cdot 2 \%$ ascorbate, and the rumen fluid could be omitted without adverse effects. When the ferrous salt was omitted from medium A, growth, as determined microscopically, was very much poorer and was only slowly improved to $c .60 \mu \mathrm{g}$. dry $\mathrm{wt}$. $/ \mathrm{ml}$. by repeated subculture in medium $\mathrm{C}$. At this stage the cultures were plated out under conditions such that each organism produced a colony and cultures were grown up from single colonies and tested for purity. No contaminants were found. Attempts to improve the growth of the organism, by the addition of sugars, amino acids, Difco Bactopeptone or Bacto-casitone, Allen and Hanbury's casein digest or papain digest of meat (White, 1950) to any of the media in the presence or absence of added iron, were unsuccessful. 
Some characteristics of the organism. The characteristics of both strains were the same. Both were anaerobes and grew with 12-24 hr. lag from an $0.5 \%$ inoculum in medium $\mathrm{C}+0.2 \%$ ascorbate in $6 \times \frac{5}{8}$ in. cotton-plugged tubes in an anaerobe jar under $95 \% \mathrm{H}_{2}+5 \% \mathrm{CO}_{2}$ or $100 \% \mathrm{H}_{2}$. Under these conditions the bacteria grew as a granular layer next to the glass. When the tubes were incubated aerobically with ascorbate or anaerobically without it there was a 2to 4-day lag before growth began: no growth occurred aerobically in the absence of ascorbate.

The organisms were Gram-negative rods $1.8-4.0 \times 0.5-0.6 \mu$ which were sometimes slightly curved and occurred occasionally in pairs or much more rarely in chains. The bacteria showed rotational and sometimes translational motility and usually showed peritrichous flagellation. Subterminal spores were formed after 1-4 weeks' incubation at $39^{\circ}$. The heat resistance of the spores of strain DL was tested by immersing in a vigorously boiling water bath a $5 \times \frac{1}{2}$ in. cotton-plugged thin-walled test tube containing the culture under test. The organisms were tested either as a 6-week culture in medium $\mathbf{C}$ per se or after centrifuging down and resuspending in salts and $0.2 \%$ ascorbate. $0.5 \mathrm{ml}$. medium was inoculated into medium $\mathrm{C}$ at intervals. The spores were still viable after $40 \mathrm{~min}$. heating under either condition. The cultures so produced were morphologically similar to the parent, produced sulphide and required sulphate for growth.

Cultures grew at $30^{\circ}, 39^{\circ}$ and $45^{\circ}$ but not at $50^{\circ}$. This failure to grow at $50^{\circ}$ and above indicated that the organism was not the thermophilic Clostridium nigrificans (Campbell, Frank \& Hall, 1957). They grew in medium $\mathrm{B}+0.02 \mathrm{M}-$ DL-alanine media at initial $\mathrm{pH}$ values from 6.0 to 8.5 , but the lag before growth began was shortest at $\mathrm{pH}$ values between 6 and 7 . When the organism was grown in a completely filled and sealed tube the final $\mathrm{pH}$ was \pm 0.5 unit that of the initial, but when growth occurred under conditions such that the sulphide produced was oxidized then the final $\mathrm{pH}$ value was $0.5-1.0$ unit higher than the initial.

The organisms did not form urease or catalase or indole. Gelatin, when added to medium $\mathrm{C}$, was not liquefied and litmus milk to which had been added sulphate, $\mathbf{0 . 2} \%$ yeast extract and ascorbate was decolorized but not clotted. The test for desulphoviridin (Postgate, 1959) was negative and the organisms therefore resembled Desulphovibrio orientis (Adams \& Postgate, 1959) rather than $D$. desulphuricans which contains this pigment.

Carbon compounds utilized for growth. The carbon compounds were tested in the presence of medium $B$ and the experiments carried out in completely filled and sealed tubes, using a $0.1 \%$ inoculum. Growth in the absence of any additions was very poor but was increased to that in the presence of $2.5 \%$ yeast extract by adding $0.01 \mathrm{M}$ - L- or D-alanine, $0.01 \mathrm{M}$-DL-lactate or $0.02 \mathrm{M}$-formate; 0.01 M-pyruvate had some stimulatory effect but growth was poorer than with the other compounds. No gas was produced with any substrate. The following compounds did not stimulate growth: (tested at $0.5 \%$ ) arabinose, dulcitol, ethanol, fructose, galactose, glucose, glycerol, inositol, inulin, lactose, maltose, mannitol, mannose, raffinose, salicin, sorbitol, starch, sucrose, 
xylose; (tested at $0.01 \mathrm{M}$ ), acetate, acrylate (also tested at $0.0012-0.005 \mathrm{M}$ ), $\beta$-alanine, $\mathrm{L}$-arginine, L-aspartate, $n$-butyrate, citrate, L-cysteine, fumarate. L-glutamate, glycine, glycollate, L-histidine, DL-isoleucine, L-leucine, L-lysine, DL-malate, DL-methionine, DL-phenylalanine, L-proline, propionate, sarcosine, DL-serine, succinate, DL-threonine, DL-tryptophan, L-tyrosine, DL-valine.

Sulphur compounds utilized for growth. No growth occurred on medium B plus $0.01 \mathrm{M}$-DL-lactate or DL-alanine when sulphate was omitted and as shown in Fig. 1 the dry weight of organisms produced during growth was proportional to sulphate concentration up to $0.006 \mathrm{M}$. However, in the presence of medium C growth occurred to a density of $50 \mu \mathrm{g}$. dry weight $/ \mathrm{ml}$. in the absence of sulphate and this was increased to $80 \mu \mathrm{g}$. dry wt./ml. by $10 \mu$ mole sulphate/ ml. As shown in Figs. 1 and 2 all the sulphate-sulphur which disappeared was accounted for as sulphide-sulphur; $c .1 \mu$ mole of sulphate was metabolized for each $10 \mu \mathrm{g}$. dry weight of bacterium produced. The sulphate was replaceable by sulphite at concentrations below $0.004 \mathrm{~m}$ but sulphite was inhibitory to growth at $0.01 \mathrm{~m}$ even in the presence of sulphate. Thiosulphate was also utilized but the maximum dry weight of organisms was only half that in the presence of sulphate although the maximum concentration of sulphide was similar. Persulphate, sulphamate, L-cysteine, sulphide and nitrate were not utilized at $0.01 \mathrm{M}$.

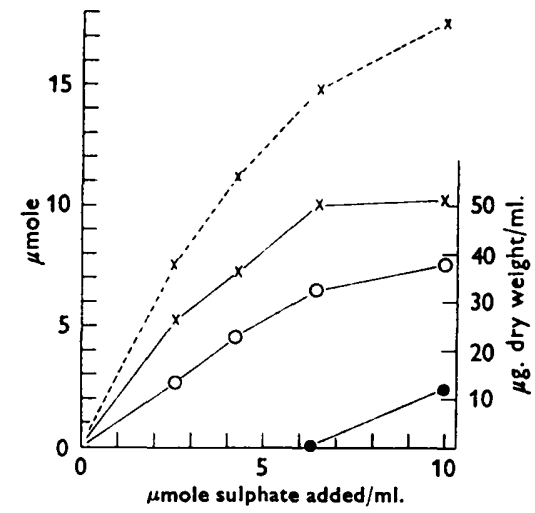

Fig. 1

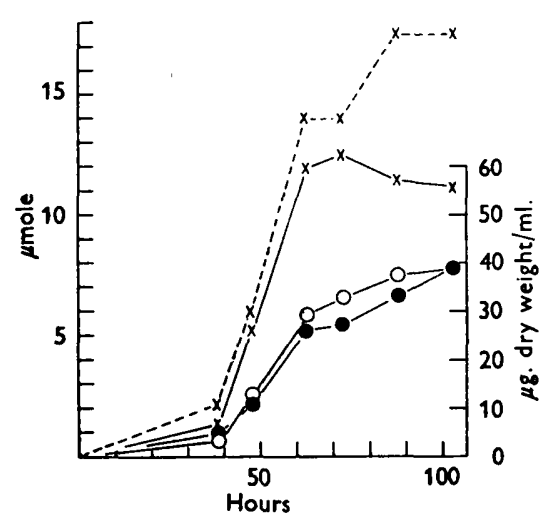

Fig. 2

Fig. 1. Effect of sulphate concentration on growth in medium B plus $0 \cdot 02 \mathrm{M}-\mathrm{DL}$-lactate from which sulphate had been omitted. Duration of experiment: $110 \mathrm{hr}$. $O$, sulphide formation; 0 , residual sulphate; $\times \cdots \times$, bL-lactate metabolized; $\times-\times$, dry weight.

Fig. 2. Time course for growth in medium B plus 0.02 M-DL-lactate. $O$, sulphide formation;

, sulphate metabolized; $x--\times$, DL-lactate metabolized; $x-x$, dry weight.

Inhibition of growth by sulphide. Figures 1 and 2 show that growth ceased when the concentration of sulphide reached $6-7 \mu \mathrm{mole} / \mathrm{ml}$. and attempts to increase the amount of organism by addition of other carbon and nitrogen compounds were unsuccessful. It was therefore possible that the sulphide produced was inhibiting further growth. To test this theory strain DL was grown in $250 \mathrm{ml}$. conical flasks containing $200 \mathrm{ml}$. medium B (with $17 \mu$ mole sulphate/ ml.) plus $22 \mu$ mole DL-lactate $/ \mathrm{ml}$. under $95 \% \mathrm{~N}_{2}+5 \% \mathrm{CO}_{2}$ until growth ceased and then the same gas was passed continuously through the culture in one 
flask to remove the sulphide. During this latter phase of growth the dry weight of organism and the amount of sulphate metabolized doubled (Table 1). When the nitrogen in the gas phase was replaced by hydrogen, the results were similar except that all the sulphate was metabolized. This suggests that the organism can use gaseous hydrogen as a hydrogen donor for sulphate reduction.

Attempts to confirm this result by growing the organism in completely filled and sealed tubes in the presence of increasing amounts of neutralized sodium sulphide were unsuccessful as growth was inhibited by $c .1 \mu \mathrm{mole} / \mathrm{ml}$. as determined directly on the growth medium after incubation. The same result was obtained whether the sodium sulphide was autoclaved or Seitz filtered and whether it was neutralized with hydrochloric or phosphoric acid before or after sterilization. All the tubes of medium containing added sulphide were slightly yellow in colour and growth inhibition may be associated with polysulphide formation.

Table 1. The effect of removal of sulphide on growth of strain $D L$

Experiment carried out in triplicate $250 \mathrm{ml}$. conical flasks containing $200 \mathrm{ml}$. medium B (containing $17 \mu$ mole $\mathrm{SO}_{4}{ }^{\prime \prime} / \mathrm{ml}$.) plus $22 \mu$ mole DL-lactate $/ \mathrm{ml}$. gassed with $95 \% \mathrm{~N}_{2}+5 \% \mathrm{CO}_{2}$. In all flasks the organism was grown from a $0.2 \%$ inoculum until growth ceased. Flask $\mathbf{A}$ was then harvested and $95 \% \mathrm{~N}_{2}+5 \% \mathrm{CO}_{2}$ (flask B) or $95 \% \mathrm{H}_{2}+5 \% \mathrm{CO}_{2}$ (flask C) passed through the other cultures for $48 \mathrm{hr}$. before harvesting.

$\begin{array}{lccr} & \text { Flask A } & \text { Flask B } & \text { Flask C } \\ \text { Dry weight }(\mu \mathrm{g} . / \mathrm{ml} .) & 61 \cdot 0 & 120 & 121 \\ \mathrm{H}_{2} \mathrm{~S}(\mu \text { mole } / \mathrm{ml} .) & \boldsymbol{7 \cdot 4} & 0 & 0 \\ \text { Sulphate disappearance } & 6 \cdot 7 & 7 \cdot 3 & 17 \\ (\mu \mathrm{mole} / \mathrm{ml}) & & & \end{array}$

Nutritional requirements. Attempts to replace the yeast extract in the medium $B+0.01 \mathrm{M}$-DL-lactate medium by a mixture of amino acids and growth factors were unsuccessful when carried out in cotton-plugged tubes incubated anaerobically in the usual way. However, when completely filled and sealed tubes were used transferable growth of both strains was obtained in the presence of basal salts $+0.01 \mathrm{M}$-DL-lactate $+0.2 \%$ ascorbate $+0.0002 \%$ $\mathrm{FeSO}_{4} \cdot 7 \mathrm{H}_{2} \mathrm{O}+0 \cdot 003 \mathrm{M}-\mathrm{NaHCO}_{3}+3 \mathrm{~m} \mu \mathrm{g} . / \mathrm{ml}$. biotin $+30 \mathrm{~m} \mu \mathrm{g} . / \mathrm{ml}$. $p$-aminobenzoic acid or folic acid. On this medium there was usually a $48 \mathrm{hr}$. lag before growth began from a $\mathbf{0 . 5} \%$ inoculum. The omission of either growth factor increased this lag to more than 7 days or abolished growth completely. When the $\mathrm{NaHCO}_{3}$ was omitted the lag was increased to 5 or more days. The organism was similar to Desulphovibrio desulphuricans (Postgate, 1956) in that it had a high requirement for iron and omission of the $\mathrm{FeSO}_{4}$ decreased markedly the final yield of organisms. On the chemically defined medium the maximum dry weight of organisms was $45 \mu \mathrm{g} . / \mathrm{ml}$. and similar results to those shown in Fig. 1 were obtained. Unfortunately it was necessary to Seitz-filter the ascorbate and sodium bicarbonate added and it is possible that other essential factors may have been leached out of the filter pad and added with these reagents.

The growth factor requirement was the same when formate was used as principal hydrogen donor for growth but under these conditions it was also necessary to add $0.001 \mathrm{M}-\mathrm{DL}$-lactate or L-alanine. 
Products of fermentation. Table 2 shows the formation of fatty acid, sulphide and ammonia during growth on medium $B$ plus various substrates. In the presence of DL-lactate, pyruvate and L-alanine 1 mole fatty acid was formed from each mole of substrate metabolized, whereas none was produced from formate. One mole of sulphide was formed for every 4 mole pyruvate and formate metabolized and every 2 mole of lactate and alanine. One mole of ammonia was also produced for each mole of alanine metabolized.

The carbon dioxide evolved during growth was measured by allowing the organisms to grow on a known amount of substrate plus medium $\mathbf{B}$ in sterile Warburg manometer flasks under $\mathrm{O}_{2}$-free nitrogen with a $\mathrm{CdCl}_{2}$ paper in the centre well; $0.5 \mathrm{ml} . \mathrm{N}-\mathrm{H}_{2} \mathrm{SO}_{4}$ was added at the end of the growth period to liberate dissolved $\mathrm{CO}_{2}$ and $\mathrm{H}_{2} \mathrm{~S}$. Table 3 shows that 1 mole of carbon dioxide was evolved per mole of formate or lactate metabolized. Unfortunately the organism grew very poorly on alanine and pyruvate under these conditions and accurate results were not obtainable.

Table 2. Fatty acid, ammonia and sulphide formation during growth on various substrates

Experiment carried out in completely filled and sealed $16 \mathrm{ml}$. tubes containing medium B plus $0.2 \%$ ascorbate and the substrate indicated; the organism was allowed to grow for $136 \mathrm{hr}$. from a $0.5 \%$ inoculum.

$\begin{array}{lcccc}\text { Substrate } & \begin{array}{c}\text { Amount added } \\ (\mu \mathrm{mole})\end{array} & \begin{array}{c}\text { Sulphide } \\ \text { formation } \\ (\mu \mathrm{mole})\end{array} & \begin{array}{c}\text { Fatty acid } \\ \text { formation } \\ (\mu \mathrm{mole})\end{array} & \begin{array}{c}\text { Ammonia } \\ \text { formation } \\ (\mu \mathrm{mole})\end{array} \\ \text { Lactate } & 10 & \mathbf{4 \cdot 2} & \mathbf{9 \cdot 0} & - \\ \text { Pyruvate } & 5 & 1 \cdot 3 & 5 \cdot 2 & - \\ \text { Alanine } & 5 & \mathbf{2 \cdot 5} & 5 \cdot 3 & \mathbf{4} \cdot 8 \\ \text { Formate } & 10 & \mathbf{2 \cdot 7} & 0 & -\end{array}$

Table 3. $\mathrm{CO}_{2}$ formation from formate and lactate during growth of strain $\mathrm{DL}$

Organism was grown from $2 \%$ inoculum in sterile Warburg manometers containing $2.2 \mathrm{ml}$. medium $\mathrm{B}$ plus $10 \mu$ mole substrate and $0.2 \%$ ascorbate under $\mathrm{O}_{2}$-free $\mathrm{N}_{2}$ at $40^{\circ}$. $\mathrm{CdCl}_{2}$ paper present.

$\begin{array}{lcccc}\text { Substrate added } & \begin{array}{c}\mathrm{H}_{2} \mathrm{~S} \text { formed } \\ (\mu \mathrm{mole} / \mathrm{ml} .)\end{array} & \begin{array}{c}\mathrm{CO}_{2} \text { formed } \\ (\mu \mathrm{mole} / \mathrm{ml} .)\end{array} & \begin{array}{c}\text { Fatty acid formed } \\ (\mu \mathrm{mole} / \mathrm{ml} .)\end{array} & \mathrm{CO}_{2} / \mathrm{H}_{2} \mathrm{~S} \\ \text { None } & \mathbf{0 \cdot 3 2} & 0 \cdot 5 & \mathbf{2 \cdot 7} & - \\ \text { Formate acid } & \mathbf{2 \cdot 7 6} & 10 \cdot 7 & \mathbf{3 \cdot 2} & \mathbf{3 \cdot 9} \\ \text { Lactate acid } & \mathbf{5 \cdot 6 4} & 10 \cdot 8 & 12 \cdot 4 & \mathbf{1 . 9}\end{array}$

The fatty acid produced from lactate, alanine and pyruvate was identified chromatographically as acetic acid. Confirmation that formic acid was absent was obtained by re-distillation with $\mathrm{MgSO}_{4}+\mathrm{HgO}$ (Friedemann, 1938). No higher fatty acids were detectable.

\section{Washed suspension experiments}

As suggested above the organism can probably use hydrogen for sulphate reduction and these washed suspension experiments were carried out in an attempt to perform this reaction quantitatively. Strain DL was used throughout this work. 
Choice of roashing and suspension media. The criterion for the suitability of these media was the ability of the final suspension to use hydrogen rapidly for the reduction of sulphate combined with a low uptake in the absence of substrate. 0.025-0.067 M-phosphate buffers were inhibitory and $0.025 \mathrm{M}$-tris (hydroxymethyl) amino methane (pH 7.1) was used routinely in the manometer flasks. All suspensions were tested in the presence or absence of $2.0 \%$ yeast extract.

The following washing and suspension media produced inactive suspensions whether used with or without $0.25 \%$ ascorbate: water, $0.067 \mathrm{M}$-phosphate buffer ( $\mathrm{pH} \mathrm{7.0)} ; \mathbf{2 . 0} \%$ gum acacia. Organisms washed and suspended in 1.0 $2 \cdot 0 \% \mathrm{NaCl}$ or basal salts less sulphate plus $0 \cdot 2 \%$ ascorbate were partially active

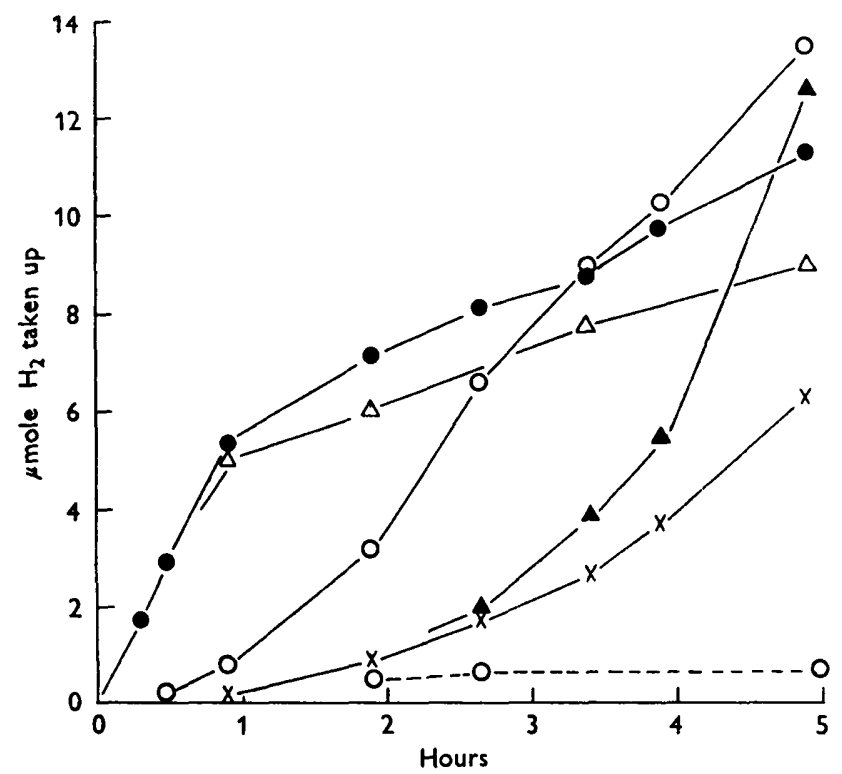

Fig. 3. Hydrogen uptake by a washed suspension in the presence of five inorganic sulphur compounds. The ratios of $\mathrm{H}_{2}$ taken up to $\mathrm{H}_{2} \mathrm{~S}$ formed, with the theoretical value for complete reduction of each substrate (in parentheses), are shown below:
$\bigcirc--O$, no added substrate $\mathbf{1 \cdot 9}$
$\Delta$, thiosulphate $\mathbf{1 \cdot 4}(\mathbf{2} \cdot 0)$
O, sulphate $2 \cdot 6(4 \cdot 0)$
$\triangle$, metabisulphite, $2 \cdot 0(\mathbf{3} \cdot 0)$
, sulphite $2 \cdot 1(3 \cdot 0)$
$\times$, persulphate $1.9(4 \cdot 0)$

when tested in the presence of $2.0 \%$ yeast extract, but the most active suspensions were those made by washing and suspending in $2.0 \%$ yeast extract plus $0.2 \%$ ascorbate. This medium was used throughout.

Desulphovibrio orientis reported by Adams \& Postgate (1959) not to contain hydrogenase did not take up hydrogen in the presence of sulphate under these conditions.

Metabolism of inorganic sulphur compounds. Figure 3 shows a time course for the uptake of hydrogen in the presence of five inorganic sulphur compounds and the final ratio of hydrogen uptake to sulphide formed. All the compounds 
tested were reduced although only sulphate and thiosulphate were readily utilized for growth. The $-Q_{\mathrm{BO}_{4}}^{\mathrm{H}_{4}}$ was usually c. 100 .

Metabolism of sulphate. Although as shown in Fig. 3 there was little gas exchange in the absence of sulphate, there was appreciable production of a gas, presumed to be carbon dioxide, when the hydrogen in the gas phase was replaced by nitrogen; this gas production was not grossly affectcd by the presence or absence of sulphate (Table 4). It was not possible to determine whether there was appreciable production of carbon dioxide under hydrogen by placing a $\mathrm{KOH}$ paper in the manometer flask as this decreased the rate of reaction by over $80 \%$. The reaction was also dependent on the absorption of sulphide throughout the experiment; when the $\mathrm{CdCl}_{2}$ paper was omitted the reaction was very slow. The following method using Dixon-Keilin flasks (Dixon, 1951) fitted with two side bulbs was adopted. The main compartment contained the bacterial suspension plus buffer and the substrate was added by knocking over a small flat-bottomed tube (vol. $0.2 \mathrm{ml}$.) which stood on the floor of the compartment. The reaction was stopped by adding $0.4 \mathrm{ml} . \mathrm{M}^{-\mathrm{H}_{3}} \mathrm{PO}_{4}$

\section{Table 4. Metabolism of sulphate by washed suspensions of strain DL}

Experiment carried out in double-side bulb Dixon-Keilin flasks in presence of $\mathrm{CdCl}_{2}$ paper at $40^{\circ}$. Organisms washed once and suspended in $2.0 \%$ yeast extract plus $0.2 \%$ ascorbate. The reaction was stopped by the addition of $0.4 \mathrm{ml} . \mathrm{M}-\mathrm{H}_{3} \mathrm{PO}_{4}$ to the main compartment and $\mathrm{CO}_{2}$ then absorbed by the admission of $\mathrm{NaOH}$ to the centre well. Gas uptake was measured both before the addition of $\mathrm{H}_{3} \mathrm{PO}_{4}$ and after the absorption of $\mathrm{CO}_{2} .36 \mu$ mole of sulphate added initially where indicated. Duration of experiment: $5 \mathrm{hr}$.

\begin{tabular}{|c|c|c|c|c|c|c|}
\hline \multirow[b]{2}{*}{$\begin{array}{l}\text { Gas } \\
\text { phase }\end{array}$} & \multirow[b]{2}{*}{$\begin{array}{l}\text { Sulphate } \\
\text { added }\end{array}$} & \multicolumn{2}{|c|}{$\mathbf{H}_{2}$ uptake } & \multirow[b]{2}{*}{$\begin{array}{c}\mathrm{CO}_{2} \\
\text { formation } \\
(\mu \text { mole })\end{array}$} & \multirow[b]{2}{*}{$\begin{array}{c}\mathbf{H}_{\mathbf{2}} \mathbf{S} \\
\text { formation } \\
(\mu \text { mole })\end{array}$} & \multirow[b]{2}{*}{$\begin{array}{c}\mathrm{SO}_{4}{ }^{\prime \prime} \\
\text { disappearance } \\
(\mu \mathrm{mole})\end{array}$} \\
\hline & & $\begin{array}{l}\text { Before acid } \\
(\mu \text { mole })\end{array}$ & $\begin{array}{c}\text { After alkali } \\
(\mu \text { mole })\end{array}$ & & & \\
\hline $\mathbf{H}$ & $\overline{+}$ & $\begin{array}{r}1 \cdot 5 \\
20 \cdot 6\end{array}$ & $\begin{array}{r}5 \cdot 8 \\
\mathbf{3 3 \cdot 2}\end{array}$ & $\begin{array}{r}1 \cdot 4 \\
16 \cdot 0\end{array}$ & $\begin{array}{l}\mathbf{1} \cdot \mathbf{3} \\
\mathbf{9} \cdot \mathbf{8}\end{array}$ & $\overline{10 \cdot 3}$ \\
\hline $\mathbf{N}_{2}$ & $\bar{t}$ & $\begin{array}{l}\mathbf{0} \\
\mathbf{0}\end{array}$ & $\begin{array}{l}\mathbf{0} \\
\mathbf{0}\end{array}$ & $\begin{array}{l}14.0 \\
12.5\end{array}$ & $\begin{array}{l}1 \cdot 4 \\
5 \cdot 0\end{array}$ & $\overline{5 \cdot 2}$ \\
\hline
\end{tabular}

from one side arm; the sulphide was absorbed on $\mathrm{CdCl}_{2}$ paper projecting from the second side arm and the $\mathrm{CO}_{2}$ absorbed at the end of the experiment by admitting $\mathrm{NaOH}$ to the centre well. The volume of hydrogen taken up was calculated from the pressure change from the addition of substrate to after the absorption of the $\mathrm{CO}_{2}$. Table 4 shows that when all the $\mathrm{CO}_{2}$ was absorbed from the gas phase the hydrogen uptake was increased by $60 \%$ and the $\mathrm{H}_{2}: \mathrm{H}_{2} \mathrm{~S}$ ratio increased from $2 \cdot 1$ to $3 \cdot 4$. In some experiments ratios as high as $4 \cdot 0$ were obtained. In an atmosphere of nitrogen, DL-lactate and L-alanine approximately doubled the production of sulphide over that in the absence of substrate when sulphate was present, whereas acetate, $n$-butyrate, formate, glucose, L-glutamate, glycerol, glycine, propionate or succinate were inactive.

Although there was good agreement between the sulphide-sulphur formed and the sulphate-sulphur which disappeared, it was possible that all of the sulphide was not formed from sulphate. To investigate this, the suspensions were allowed to metabolize ${ }^{35} \mathrm{SO}_{4}$ and the distribution of ${ }^{35} \mathrm{~S}$ determined. 
Over $95 \%$ of the sulphate-sulphur which disappeared was found as sulphidesulphur and the specific activity of the sulphide (after subtraction of the sulphide production in absence of sulphate) was the same as the sulphate. Less than $0.5 \%$ of the ${ }^{35} \mathrm{~S}$ was found in the organisms.

Inhibition of sulphate reduction by selenate. In the presence of $20 \mu$ mole sulphate, $2 \cdot 0 \mu$ mole selenate decreased the sulphide production by over $80 \%$ and $0.2 \mu$ mole selenate decreased it by $15 \%$. This result is similar to that found with Desulphovibrio desulphuricans by Postgate (1949).

\section{DISCUSSION}

The bacterium described here differs from Desulphovibrio desulphuricans (Postgate, 1958) in that it forms spores, has different flagellation and does not contain desulphoviridin, from $D$. rubentshickii and its variant anomalous (Baars, 1930) in that it does not utilize acetate or butyrate and from Clostridium nigrificans (Campbell et al. 1957) in that it does not grow at 50 ${ }^{\circ}$ However, it closely resembles Desulphovibrio orientis (Adams \& Postgate, 1959) in its spore formation, mesophilic growth and absence of desulphoviridin although it differs in its peritrichous flagellation, presence of hydrogenase and in the final yield of organisms in medium B plus lactate of $50 \mu \mathrm{g}$. dry wt./ml. (about $25 \%$ of that of D. orientis).

Theoretically eight atoms of hydrogen are necessary for the reduction of each molecule of sulphate or thiosulphate to sulphide as shown below, and Postgate (1951) working with Desulphovibrio desulphuricans obtained values close to the theoretical:

$$
\begin{aligned}
& 8[\mathrm{H}]+\mathrm{SO}_{4}{ }^{\prime \prime} \rightarrow 4 \mathrm{H}_{2} \mathrm{O}+\mathrm{S}^{\prime \prime} \\
& 8[\mathrm{H}]+\mathrm{S}_{2} \mathrm{O}_{3}{ }^{\prime \prime} \rightarrow 3 \mathrm{H}_{2} \mathrm{O}+2 \mathrm{HS}^{\prime \prime} .
\end{aligned}
$$

From the ratios of substrate metabolized to sulphide formed shown in Table 2 it is apparent that each molecule of alanine and lactate donate four atoms of hydrogen when completely metabolized, whereas pyruvate and formate donate only two atoms of hydrogen. To explain the results the following scheme, which is similar to that proposed for lactate metabolism by Desulphovibrio desulphuricans by Ishimoto, Koyama, Omura \& Nagai (1954) and Grossman \& Postgate (1955), is put forward.

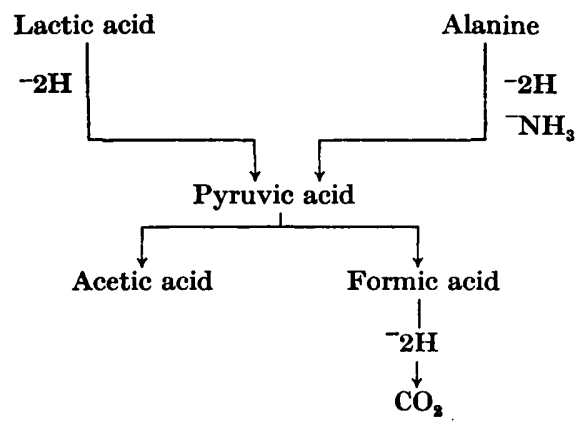

The validity of this scheme is supported by: $(a)$ the two intermediates in alanine and lactate metabolism, i.e. pyruvate and formate were both meta- 
bolized, whereas acetate and many other compounds were not; $(b)$ approximately 1 mole of acetate was produced per mole of lactate, pyruvate and alanine metabolized, whereas none was produced from formate; (c) 1 mole of $\mathrm{CO}_{2}$ was produced per mole of lactate and formate metabolized. Acrylate which is a possible intermediate in lactate and alanine metabolism was not metabolized.

The growth of the organism was apparently limited by the maximum concentration of sulphide tolerated, i.e. $6-7 \mu \mathrm{mole} / \mathrm{ml}$., although this was not demonstrated directly and when the sulphide was removed growth continued above the normal level. Confirmatory evidence is provided by the results for growth on thiosulphate where 2 mole of sulphide were produced per mole of thiosulphate metabolized and the maximum dry weight of bacteria was halved compared with growth on sulphate. The maximum sulphide concentration produced by Desulphovibrio desulphuricans is considerably greater than this, i.e. $23 \mu \mathrm{mole} / \mathrm{ml}$. (Baars, 1930), $60-70 \mu \mathrm{mole} / \mathrm{ml}$. (Miller, 1949), or $96 \mu \mathrm{mole} / \mathrm{ml}$. (Butlin \& Postgate, 1953) for the organism growing in continuous culture. Although the organism utilized very few compounds as hydrogen donors for growth it had wide biosynthetic abilities and required only two growth factors. The biosynthetic pathways involved in the synthesis of the amino acids are being investigated. Interpretation of the results with washed suspensions is complicated by the complex nature of the suspension medium but, as shown in Table $4, \mathrm{H}_{2}: \mathrm{H}_{2} \mathrm{~S}$ ratios approaching the value of 4 demanded by theory were obtained.

The author wishes to thank Dr D. Kerridge for carrying out the flagella staining and Miss C. M. Tebbutt and Miss J. M. How for their valuable technical assistance.

\section{REFERENCES}

Adams, M. E. \& Postgate, J. R. (1959). A new sulphate-reducing vibrio. J. gen. Microbiol. 20, 252.

Anderson, C. M. (1956). The metabolism of sulphur in the rumen of the sheep. N.Z. J. Sci. Tech. A, 37, 379.

BaARS, J. K. (1930). Over sulphaatreductie door bacterien. Dissertation, Meinema: Delft.

Barker, S. B. \& Summerson, W. H. (1941). The colorimetric determination of lactic acid in biological materials. J. biol. Chem. 138, 535.

Bцоск, R. J. \& Stekol, J. A. (1950). Synthesis of sulphur amino acids from inorganic sulphate by ruminants. Proc. Soc. exp. Biol., N.Y. 73, 391.

Block, R. J., Stekol, J. A. \& Loosu, J. K. (1951). Synthesis of sulphur amino acids from inorganic sulphate by ruminants. II. Synthesis of cystine and methionine from sodium sulphate by the goat and by microorganisms of the rumen of the ewe. Arch. Biochem. Biophys. 33, 353.

Butlin, K. R., Adams, M. E. \& Thomas, M. (1949). The isolation and cultivation of sulphate-reducing bacteria. J. gen. Microbiol. 3, 46.

Butun, K. R. \& Postgate, J. R. (1953). Microbiological formation of sulphide and sulphur. Symp. 6th int. Congr. Microbiol. p. 126.

Campaell, L. L., Frank, H. A. \& Hall, E. R. (1957). Studies on thermophilic sulphate-reducing bacteria. 1. Identification of Sporovibrio desulfuricans as Clostridium nigrificans. J. Bact. 73, 516. 
Coleman, G. S. (1956). The dissimilation of amino acids by Rhodospirillum rubrum. J. gen. Microbiol. 15, 248.

Colfman, G. S. (1958). The incorporation of amino acid carbon by Rhodospirillum rubrum. Biochim. biophys. Acta, 30, 549.

Coldeman, G. S. (1959). The isolation and some properties of a sulphate-reducing bacterium from the sheep rumen. J. gen. Microbiol. 21, i.

Dixon, M. (1951). Manometric Methods. Cambridge University Press.

Elsden, S. R. \& Lewis, D. (1953). The production of fatty acids by a Gram-negative coccus. Biochem. J. 55, 183.

Emery, R. S., Smith, C. K. \& FAI To, L. (1957). Utilisation of inorganic sulphate by rumen microorganisms. II. The ability of single strains of rumen bacteria to utilise inorganic sulphate. Appl. microbiol. 5, 363.

Emery, R. S., Smith, C. K. \& Hufrman, C. F. (1957). Utilisation of inorganic sulphate by rumen microorganisms. I. Incorporation of inorganic sulphate into amino acids. Appl. microbiol. 5, 360.

Friedemann, T. E. (1938). The identification and quantitative determination of volatile alcohols and acids. J. biol. Chem. 123, 161.

Grossman, J. P. \& Postgate, J. R. (1955). The metabolism of malate and certain other compounds by Desulphovibrio desulphuricans. J. gen. Microbiol. 12, 429.

Gutierrez, J. (1953). Numbers and characteristics of lactate utilising organisms in the rumen of cattle. J. Bact. 66, 123.

Ishimoto, M., Koyama, J., Omura, T. \& NagaI, Y. (1954). Sulphate reducing bacteria. 3. Sulphate reduction by cell suspensions. J. Biochem., Tokyo, 41, 537 .

Lewis, D. (1954). The reduction of sulphate in the rumen of the sheep. Biochem. $J$. $56,391$.

Markham, R. (1942). A steam distillation apparatus suitable for micro-Kjeldahl analysis. Biochem. J. 36, 790.

Mrller, L. P. (1949). Rapid formation of high concentrations of hydrogen sulphide by sulphate-reducing bacteria. Contr. Boyce Thompson Inst. 15, 437.

Obermer, M. E. \& Mrlton, R. (1932). Méthode photométrique pour l'analyse du soufre urinaire (avec étude sur la stabilité colloidale des précipités sulfatiques). Bull. Soc. Chim. biol., Paris, 14, 1447.

Postgate, J. R. (1949). Competitive inhibition of sulphate reduction by selenate. Nature, Lond. 164, 670.

Postgate, J. R. (1951). The reduction of sulphur compounds by Desulphovibrio desulphuricans. J. gen. Microbiol. 5, 725.

Postgate, J. R. (1953). On the nutrition of Desulphovibrio desulphuricans: a correction. J. gen. Microbiol. 9, 440.

Postgate, J. R. (1956). Iron and the synthesis of cytochrome $\mathrm{C}_{3}$. J. gen. Microbiol. $15,186$.

Postgate, J. R. (1958). The chemical physiology of sulphate-reducing bacteria. Prod. Mon. 22, 12.

Postgate, J. R. (1959). A diagnostic reaction of Desulphovibrio desulphuricans. Nature, Lond. 183, 481.

Vogel, A. I. (1948). A Text Book of Quantitative Inorganic Analysis. London: Longmans, Green and Co.

White, R. W. (1950). Digest culture media using paw-paw (Carica papaya) in the tropics. Brit. vet. J. 106, 201.

(Received 27 August 1959) 